\title{
THE RELATION OF MAJAPAHIT TEMPLES WITH VASUSASTRA-MANASARA
}

\author{
${ }^{1}$ Ruth Meiliani Surya. ${ }^{2}$ Dr. Rahadhian Prajudi Herwindo, S.T., M.T. \\ ${ }^{1}$ Student in the Bachelor's (S-1) Study Program in Architecture \\ at Parahyangan Catholic University \\ ${ }^{2}$ Senior lecturer in the Bachelor's (S-1) Study Program in Architecture \\ at Parahyangan Catholic University
}

\begin{abstract}
Vastusastra is a text which discusses Indian architecture which is published in several books, included Manasara. Vastusastra contains guidline for building Indian construction, including religious building such as temples. Although the narrative was made for the construction of temples in India, it turns out that there are some elements in vastu that also found in Mataram Kuno temples. This raises questions about the relationship of Indian architecture with Majapahit, which was the era after Ancient Mataram, given the Hindu-Buddhist influence still existed in the Majapahit era. To find out this, vastusastra-Manasara was used as a benchmark to find out the elements of the Majapahit temple which was influenced by India, especially South India which was thought to have a more dominant influence than North India on temple architecture in Indonesia.

This study uses a descriptive method with a qualitative approach by describing the figure and massspace layout of Majapahit temples that have been selected as the object of research and compared with vastusastra-Manasara's narrative using reference objects to facilitate analysis in order to find out the relations of the Majapahit era temples with vastusastra-Manasara narrative.

Based on the results of the study, it was found that the temples of the Majapahit era still have relations with vastusastra-Manasara narrative when viewed in terms of figure and mass-space layout. But the relationship between the two can be said to be increasingly decreased. The re-domination of the original culture of Indonesian society in the Majapahit era and the influence of other cultures such as China is thought to be the cause of the waning influence of India on the architecture of the Majapahit temple. This led to the fusion of culture in the Majapahit temple and resulted in variations of new temples that had never existed before.
\end{abstract}

Key Words: candi, majapahit, temple, vastusatra, manasara, relation

\section{KAJIAN RELASI ARSITEKTUR CANDI ERA MAJAPAHIT DENGAN VASTUSASTRA-MANASARA}

\author{
${ }^{1}$ Ruth Meiliani Surya. ${ }^{2}$ Dr. Ir. Harastoeti Dibyo Hartono, MSA \\ ${ }^{1}$ Mahasiswa S1 Program Studi Arsitektur Universitas Katolik Parahyangan. \\ 2 Dosen Pembimbing S1 Program Studi Arsitektur Universitas Katolik Parahyangan.
}

\begin{abstract}
Abstrak- Vastusastra adalah teks sastra yang membahas ilmu arsitektur India yang dimuat dalam beberapa kitab termasuk Manasara. Vastusastra biasanya berisi penuturan atau pedoman untuk membangun bangunan di India, tak terkecuali bangunan peribadatan seperti kuil. Meskipun penuturannya dibuat untuk pembangunan kuil di India, ternyata terdapat beberapa elemen vastu yang ditemukan juga pada candi-candi era Mataram Kuno. Hal tersebut menimbulkan pertanyaan mengenai hubungan arsitektur India dengan Majapahit yang merupakan era setelah Mataram Kuno, mengingat pengaruh Hindu-Buddha masih ada pada era Majapahit. Untuk mengetahui hal tersebut, vastusastra-Manasara digunakan sebagai tolak ukur untuk mengetahui adanya elemen candi Majapahit yang mendapat pengaruh dari India, terutama India Selatan yang diduga memiliki pengaruh yang lebih dominan ketimbang India Utara pada arsitektur candi di Indonesia.

Penelitian ini menggunakan metode deskriptif dengan pendekatan kualitatif dengan cara mendeskripsikan sosok dan tata massa-ruang candi-candi Majapahit yang telah dipilih menjadi objek penelitian dan dikomparasi dengan penuturan vastusastra-Manasara menggunakan objek referensi untuk mempermudah analisis guna mencari tahu relasi candi-candi era Majapahit dengan penuturan vastusastra-Manasara.

Berdasarkan hasil penelitian, ditemukan bahwa candi-candi era Majapahit masih memiliki relasi dengan penuturan vastusastra-Manasara apabila dilihat dari segi sosok dan tata massa-ruangnya. Namun relasi keduanya
\end{abstract}

\footnotetext{
${ }^{1}$ Corresponding Author: ruthmeilianiwork@gmail.com
} 
dapat dikatakan semakin mengalami penurunan apabila dibandingkan dengan era-era sebelum Majapahit. Munculnya dominasi kembali budaya asli masyarakat Indonesia era Majapahit dan pengaruh kebudayaan lain seperti China diduga menjadi penyebab semakin memudarnya pengaruh India pada arsitektur candi Majapahit. Hal tersebut menyebabkan peleburan kebudayaan dalam candi Majapahit dan menghasilkan variasi candi baru yang belum pernah ada sebelumnya.

Kata Kunci: candi, majapahit, kuil, vastusastra, manasara, relasi

\section{PENDAHULUAN}

Adanya akulturasi budaya pendatang dan lokal (local genius) maka lahirlah peninggalan-peninggalan dari kerajaan-kerajaan Hindu-Budha di Indonesia, salah satunya yaitu candi-candi. Berdasarkan penelitian Aditya Bayu P. mengenai kajian relasi antara candi Mataram Kuno dengan Vāstuśāstra, diperoleh kesimpulan bahwa candi-candi Kerajaan Mataram Kuno memiliki kemiripan dengan kuil-kuil di India Selatan. Diketahui, candi era Mataram Kuno masih menggunakan ilmu Vāstuśāstra dalam membangun candi-candinya meskipun tidak digunakan secara keseluruhan karena telah dipadukan dengan budaya lokal. Vāstuśástra sendiri merupakan dasar-dasar yang mengatur kehidupan masyarakat di India. Ilmu Vāstuśāstra dirangkum dalam beberapa buku. Buku yang membahas tentang arsitektur salah satunya adalah Kitab Mānasāra.

Oleh karena itu, perlu adanya penelitian lanjutan pada candi-candi setelah era Mataram Kuno karena secara sekilas dapat dilihat bahwa terdapat perubahan sosok, tata massa, dan tata ruang dari masa ke masa yag diduga merupakan akibat perubahan pola peribadatan, sosial dan politik yang terjadi pada era Majapahit . Hal ini dibuktikan juga dengan ukuran candi-candi yang semakin kecil namun lebih bersifat menyebar apabila dibandingkan dengan candi-candi pada era Mataram Kuno. Kerajaan Majapahit menjadi 'penerus' keberlangsungan kerajaan bertema Hindu di Indonesia setelah Mataram Kuno runtuh. Oleh karena itu, penelitian kali ini memfokuskan objek studi pada candi-candi peninggalan Kerajaan Majapahit untuk mengetahui seberapa besar pengaruh kebudayaan India dalam bidang asitektur yang masih tertinggal pada masa Majapahit melalui Vāstuśāstra-Mānasāra sebagai tolak ukur adanya elemen arsitektur dari kuil Hindu di India.

\section{KAJIAN TEORI}

\subsection{VASTUSASTRA-MANASARA}

Vāstuśāstra bukan merupakan ilmu yang statis namun terus berkembang dengan berbagai variasi penerapan di antara masyarakat India dan Asia Tenggara. Kitab Mānasāra yang disusun pada abad ke $6 \mathrm{M}$ merupakan kitab klasik pertama dengan topik tunggal vāstu dan arsitektur. Meskipun tidak diketahui dengan pasti sejauh mana prinsip-prinsip Vāstuśāstra diterapkan secara konkret, berbagai kitab berisi Vāstuśāstra ditulis sebagai upaya perwujudan pandangan kosmologi dan seni ideal dalam kehidupan sosial dan spiritual masyarakat Hindu. Mānasāra sendiri adalah sebuah kitab yang berisikan teks-teks Vāstuśāstra yang membahas tentang panduan arsitektural dalam membangun bangunan seperti kuil. Secara etimologi, sāra berarti esensi sedangkan māna berarti ukuran, sehingga mānasāra berarti 'the essence of measurement'. Dengan kata lain, mānasāra dapat disebut sebagai 'standar pengukuran' atau 'sistem proporsi' dalam bidang arsitektur. Kitab ini umum dirujuk dengan judul singkat seperti di atas, namun penutup dari tujuh puluh bagian dari kitab tersebut memberikan judul lengkap Mānasāra Vāstuśāstra atau Mānasāra Silpaśāstra.

\subsection{KUIL HINDU DI INDIA}


Kuil merupakan tempat suci yang digunakan untuk melakukan aktivitas keagamaan dan sebagai representasi atau simbolisasi nilai-nilai keagamaan dalam bentuk arsitektur. Dalam bahasa lain, kuil biasa disebut kovil/ koil (Tamil), mandira (Sansekerta), dan lain-lain. Kuilkuil biasanya dibuat agar dapat menghadirkan semesta yang mengundang kehadiran dewadewa sehingga letak dan pembangunan kuil tidak dapat dilakukan dengan semena-mena.

\subsubsection{SOSOK BANGUNAN}

Karakter dari sebuah kuil Hindu direfleksikan berdasarkan arsitektur lokal daerah tersebut serta didukung material dan keahlian yang mendukung pada daerah tersebut. Oleh karena itu, di India sendiri terdapat tiga gaya kuil. Berdasarkan letaknya, tipe kuil Hindu di India diagi menjadi Nagara (India Utara), Dravida (India Selatan), dan Vesara (gabungan/ timur).

Tabel 1. Tipe Kuil Hindu di India

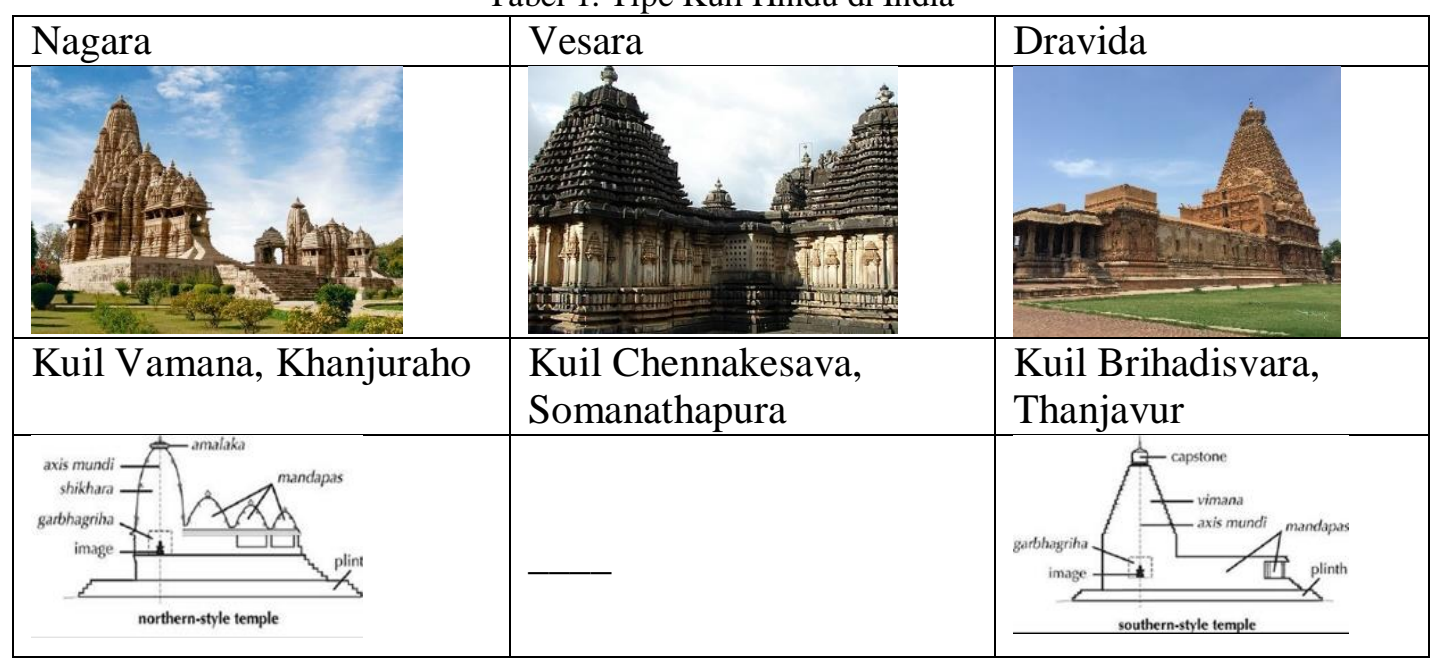

Sosok bangunan kuil di India dibagi menjadi beberapa bagian seperti kemuncak/ stupi, sikhara (bagian dari puncak), gala (penghubung antara puncak dan menara), tala (satuan tingkat pada atap), prastara (atap), karnakuta (miniatur ada bagian atap), garbagrha, pada (dinding), adhistana (umpak) dan upapitha (pedestal) yang akan dijelaskan pada sub bab berikutnya berikut contoh penerapannya. Enam hingga tujuh bagian ini dapat ditemukan dalam Manasara dengan detil pembahasan yang bervariasi. Masing-masing memiliki pembahasan tersendiri pada bab XIII, XV, dan XVI kecuali bagian stupi, gala, dan sikhara yang pembahasannya tersebar dalam bab-bab Manasara.

\subsubsection{TATA MASSA-RUANG}

Kitab Mānasāra juga berisi mandala-mandala yang banyak digunakan dalam membangun bangunan peribadatan di India. Namun, disebutkan bahwa mandala-mandala yang dijabarkan tidak sebatas itu saja tapi juga dapat mengikuti bentuk tapak. Oleh karena itu, pada kitab terjemahan Mānasāra oleh Acharya, dijabarkan banyak bentuk mandala. 


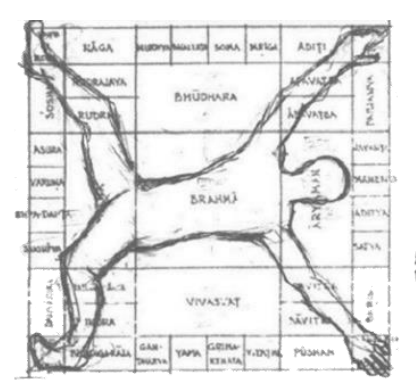

Vastupurusha Mandala menurut Manasara

disadur dari Aditya Bayu P (2018)

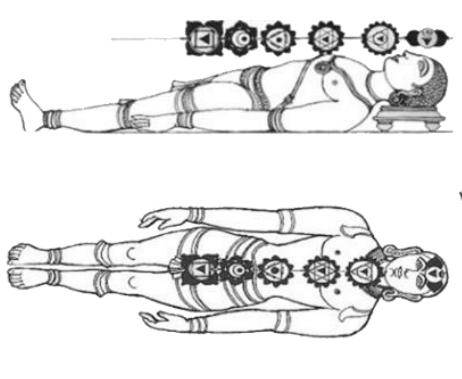

Mandala Linear yng berisi elemen chakra (dianggap sesuai degan vastupurusha Mandala

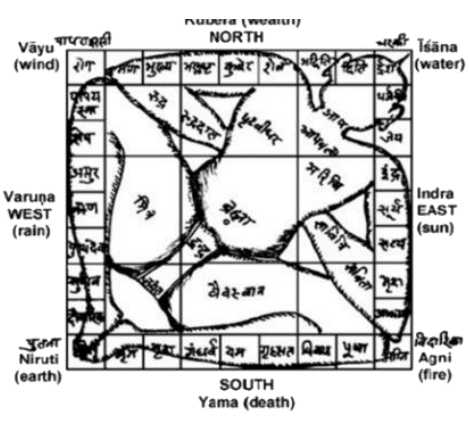

Vastupurusha Mandala yang telah disepakati (abad ke-15)

Gambar 1. Vastupurusha Mandala

Mandala linear berisi elemen chakra yang diwujudkan dalam tata massa-ruang kuil di India. Di bawah ini merupakan beberapa elemen chakra pada mandala linear.

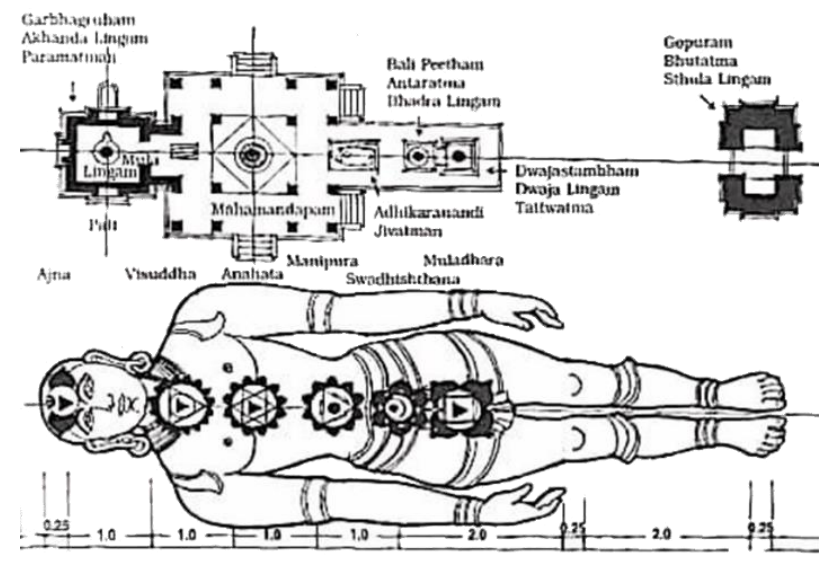

Gambar 2. Mandala Linear Sumber: Google

\subsubsection{OBJEK REFERENSI:KUIL BRIHADISVARA}

Objek yang dipilih sebagai referensi adalah Kuil Brihadisvara yang terletak di Thanjavur di India Selatan. Objek ini dipilih karena dibangun sebelum candi-candi di Majapahit di bangun, yaitu abad ke-10 Masehi dan berada di India Selatan yang diduga memiliki banyak kesamaan dengan candi-candi di Indonesia. Kuil Brihadisvara dibangun berdasarkan vastusastra-Manasara sehingga elemen-elemen pada kuil Brihadisvara dapat dijadikan referensi nyata dari penuturan Manasara. 


\section{Gambar 3. Pembagian Sosok Kuil Brihadisvara menurut Manasara}

Sedangkan pada tata massa dan ruang Kuil Briadisvara, ditemukan elemen-elemen dari mandala linear yang telah disebutkan pada sub bab sebelumnya. Selain itu, Kuil Brihadisvara memiliki tiga halaman yang dibagi dengan adanya gerbang atau gopuram. Diduga fungsi gopuram dan dinding pagar sebagai benteng perlindungan akibat ketegangan sosial politik yang terjadi pada masa tersebut. Kuil utama Brihadisvara memiliki arah hadap ke timur yang berarti merupakan tempat peribadatan apabila mengaju pada konsep pradaksina (adaptasi gerakan matahari searah jarum jam). Di bawah ini merupakan pembagian area dan tata massa pada kompleks Kuil Brihadisvara beserta alur peribadatannya.

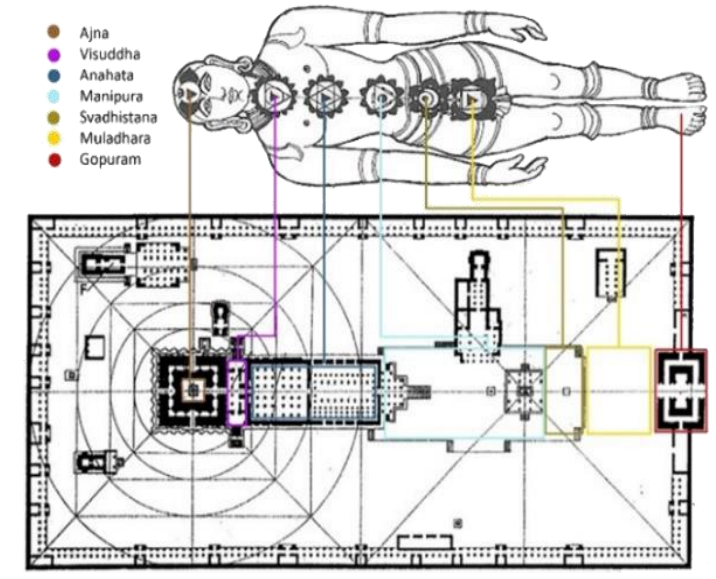

Gambar 4. Tata Massa Kuil Brihadisvara berdasarkan Mandala Linear

Bangunan utama Kuil Brihadisvara memiliki satu ruang dalam ( garbagrha) yang hanya dapat dimasuki oleh pendeta dan orang-orang tertentu saja. Ruang dalam bangunan utama tersebut berisi lingga (arca/ patung yang disembah). Di samping ruang garbagrha, terdapat area yang digunakan sebagai jalan untuk mengitari garbagrha pada saat upacara peribadatan yang disebut pradakshina. 


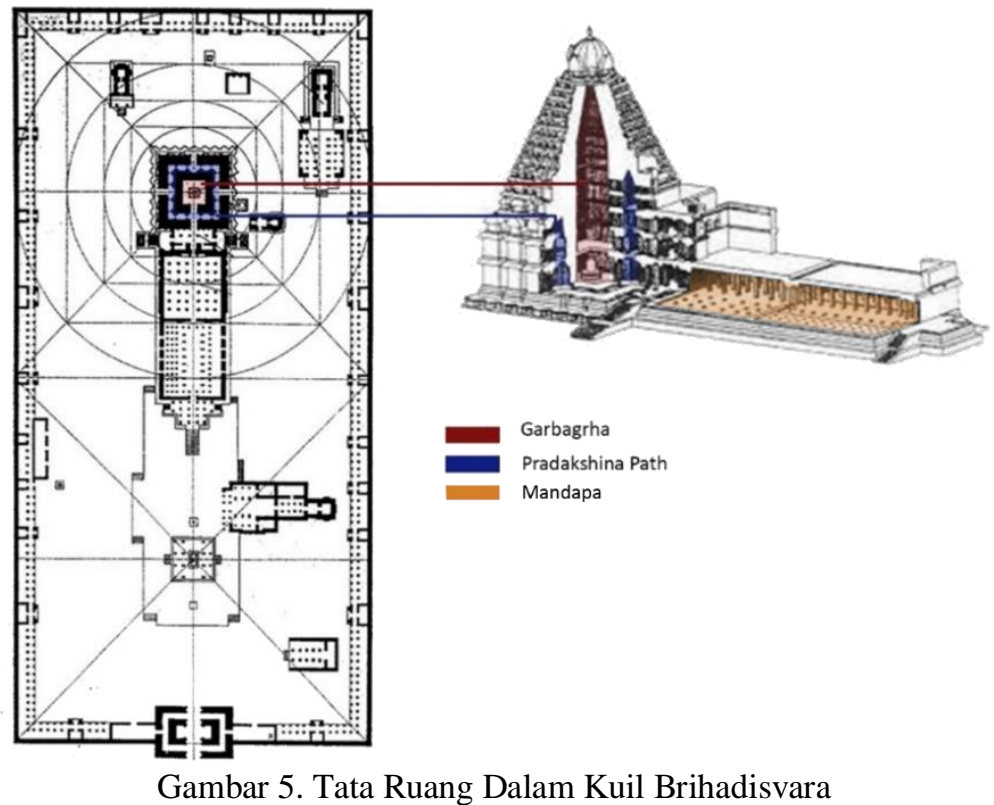

\subsection{CANDI MAJAPAHIT}

Berdasarkan kitab Pararaton dan Nagarakertagama, dapat diyakini bahwa pembangunan candi pada era Majapahit bertalian erat dengan peristiwa wafatnya seorang raja. Sebuah candi didirikan untuk mendharmakan atau memuliakan roh raja yang telah bersatu dengan dewa. Kitab Nagarakertagama menggambarkan upacara sraddha untuk mengenang wafatnya raja Wishnuwardhana sebagai upacara terakhir dari serangkaian upacara penyucian dan penyempurnaan roh setelah Wishnuwardhana wafat lebih dari dua belas tahun.

Candi-candi Majapahit merupakan bukti adanya hubungan yang erat antar agama Hindu dan Buddha. Hal ini dapat dibuktikan dnegan adanya relief cerita yang berlatar belakang agama Hindu (Siwa dan Waisana) dan Buddha sekaligus dalam satu bangunan peribadatan/ candi. Hubungan ini juga dapat diketahui dari bentuk bangunan dan arca pemujaannya. Sebagai contoh, dalam pupuh LVI Negarakertagama disebutkan bahwa Candi Jawi, tempat pendharmaan Raja Kertanegara berkaki Siwa dan berpuncak Buddha.

Selain dipengaruhi oleh agama Hindu dan Buddha, candi-candi Majapahit juga dipengaruhi oleh kepercayaan masyarakat terdahulu yang memuja arwah nenek moyang. Kepercayaan ini sudah tertanam dalam masyarakat Indonesia bahkan sampai saat ini sejak zaman prasejarah atau lebih tepatnya zaman Neolitikum. Kepercayaan ini sempat pudar pada era Mataram Kuno. Hal ini dapat dilihat dari peninggalan candi-candinya seperti Prambanan yang sangat erat dengan pengaruh Hindu. Meskipun begitu, pada era Majapahit, pemujaan terhadap nenek moyang seakan kembali mendominasi.

Salah satu faktor yang mendorong berkembangnya kepercayaan tersebut adalah situasi sosial politik yang mengalami goncangan akibat masuknya agama Islam ke Jawa. wilayah kekuasaan Majapahit terutama yang berada di daerah pantai banyak yang melepaskan diri dari Majapahit dan membentuk agama-agama Islam. Situasi tersebut mempengaruhi daerah pedalaman sebagai daerah yang dekat dengan pusat pemerintahan dan pusat berkembangnya agama Siwa.

\subsubsection{SOSOK BANGUNAN}




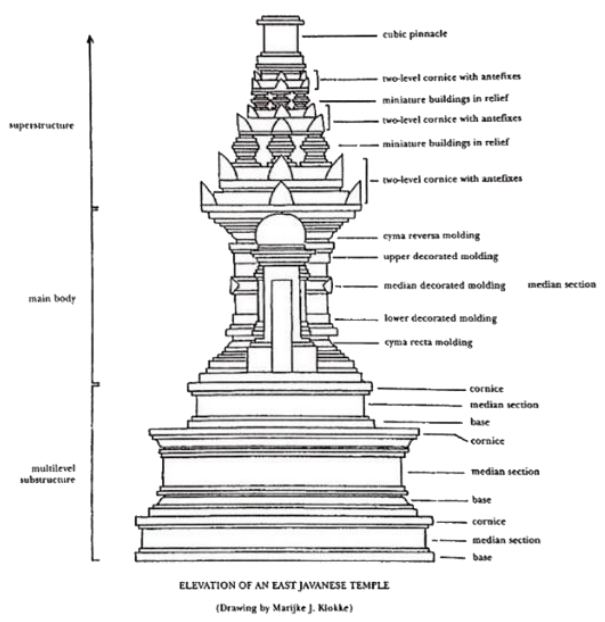

Gambar 6. Pembagian Tiga Sosok Candi Majapahit Mengikuti Kosmologi Hindu menurut Marjke J. Klokke Sumber: The Temple Art of East java: Worshippig Siva and Buddha (2003)

Dalam berbagai literatur candi Jawa yang ditulis di Indonesia, umumnya candi terbagi menjadi tiga bagian; kaki, badan, dan kepala. Pembagian tiga ini merupakan perwujudan konsep kosmologi Hindu yang membagi alam semesta menjadi tiga bagian; bhurloka (alam bawah/ alam manusia), bhuvarloka (alam tengah/ alam bagi yang sudah disucikan), dan svarloka (alam atas/ alam para dewa). Pada bagian tengah atau badan, manusia yang sudah menyucikan dirinya sendiri dapat bertemu dengan nenek moyangnya yang sudah bersatu dengan para dewa. Perbedaan Sosok candi Majapahit dengan era sebelumnya, yaitu Mataram Kuno adalah akibat dari adanya letusan gunung merapi dan perang saudara yang terjadi antara kedua era tersebut.

\subsubsection{TATA MASSA-RUANG}

Tata massa candi-candi di Jawa telah diidentifikasi oleh beberapa peneliti seperti Degroot (2009) dan Herwindo (1999) menjadi beberapa kategori. Namun, tata massa candi era Majapahit umumnya linear (P7) dengan beberapa halaman dalam satu kompleks candi. Halaman-halaman tersebut dibatasi oleh gerbang dan / atau dinding (meskipun, sekarang ini banyak dinding yang sudah hancur). Hal ini menimbulkan hirarki sekaligus alur bagi pengunjung atau pelaku peribadatan. Apabila dilihat secara sekilas, gerbang pada kompleks candi-candi Majapahit umumnya tidak berada di tengah namun seikit bergeser ke kanan atau ke kiri.

Sedangkan tata ruang dalam candi cukup sederhana karena umumnya hanya memiliki satu ruang dalam pada candi utamanya. Pada ruang dalam candi umumnya terdapat lingga-yoni (simbol kejantanan dan kesuburan) atau arca Siwa sebagai objek yang disembah. Ruang dalam pada candi bersifat tertutup dan gelap diduga merupakan perwujudan alam semesta yang juga gelap.

\subsection{CANDI-CANDI MAJAPAHIT}

Candi-candi yang dipilih sebagai objek penelitian adalah Candi Kidal, Sukuh, Ceto, Jawi, Jago, Panataran.

\section{METODE PENELITIAN}

Melalui latar belakang ini, penelitian difokuskan kepada bagaimana relasi arsitektur candi Majapahit dengan vastusastra-Manasara. Penelitian yang dilakukan bersifat kualitatif, dengan menggunakan metode analisis deskriptif. Analisa dilakukan dengan membandingkan 
elemen sosok dan tata massa-ruang pada candi Majapahit dan vastusastra-Manasara. Perbandingan tersebut dibantu dengan adanya objek referensi sebagai perwujudan dari teks vastu. Objek studi penelitian yang digunakan adalah candi-candi Majapahit (Candi Kidal, Candi Jawi, Candi Panataran, Candi Jago, Candi Ceto, dan Candi Sukuh)

\section{ANALISIS}

\section{RELASI CANDI MAJAPAHIT DENGAN VASTUSASTRA-MANASARA}

\subsection{SOSOK BANGUNAN}

\subsubsection{STUPI}

Apabila dilihat dari keenam objek studi, candi yang memiliki stupi hanyalah Candi Jawi. Hal ini diduga karena Candi Jawi mendapat pengaruh Buddha dan juga Hindu. Perpaduan kedua pengaruh di atas merupakan hasil kepercayaan Raja Ketanegara. Adanya stupi pada puncak candi merupakan hal yang unik dalam arsitektur candi di Jawa Timur. Hal ini dapat diketahui dari dihilangkannya elemen stupi dari candi-candi Majapahit yang lain. Kepercayaan Hindu mentafsirkan dewa sebagai kosmologi yang abstrak sehingga tidak diwujudkan dalam bentuk stupi seperti pada contoh Candi Kidal yang menghilangkan bagian stupi sebagai simbolisme dari abstrak.

Tabel 3. Perbandingan Stupi Kuil Brihadisvara dengan Candi Jawi

\begin{tabular}{|l|l|l|}
\hline \multicolumn{2}{|c|}{ INDIA } & \multicolumn{2}{c|}{ JAWA Perspektif } \\
\hline Tampak & Perspektif & Tampak \\
\hline Kuil Brihadisvara, Thanjavur
\end{tabular}

\subsubsection{SIKHARA}

Apabila dibandingkan dengan Kuil Brihadisvara sebagai referensi objek studi, maka dapat diketahui bahwa ukuran sikhara pada Candi Jawi maupun Kidal relatif lebih kecil dan memiliki bentuk persegi. Bentuk persegi tersebut diduga diperoleh dari bentuk pripih yang direpresentasikan ke atas. Selain itu, sikhara pada Candi Jawi terlihat lebih menyatu dengan bagian stupi-nya sehingga lebih sulit untuk dibedakan apabila dibandingkan dengan sikhara pada Kuil Brihadisvara. Sedangkan, sikhara pada candi Candi Kidal sudah tidak dapat dilihat dalam bangunan aslinya karena telah hilang/ hancur. 


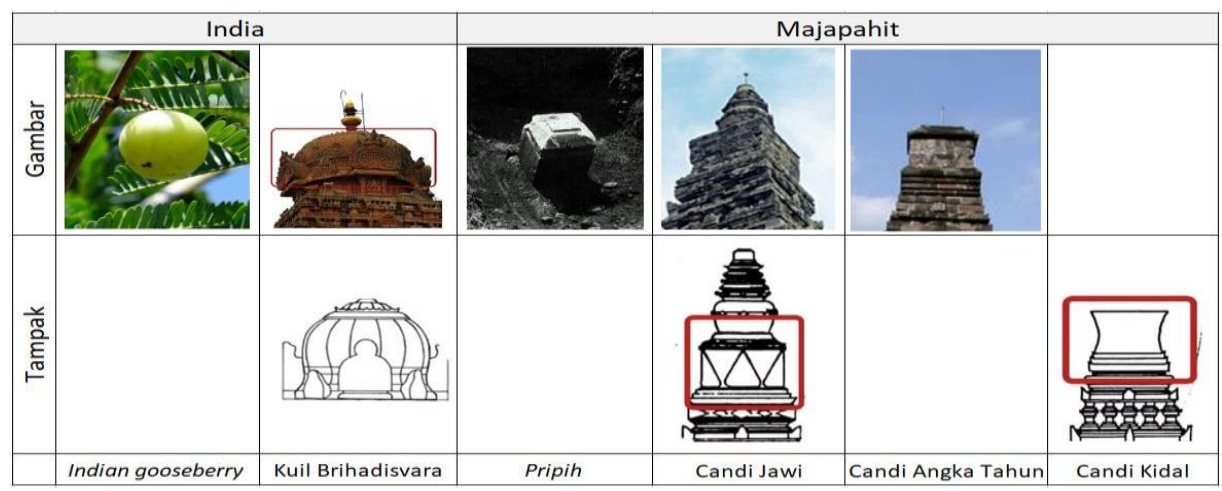

\subsubsection{GALA}

Gala merupakan bagian dari puncak kuil yang merupakan leherr atau penghubung antara tala terakhir pada prastara dengan sikhara. Seperti yang dikatakan sebelumnya, gala pada Candi Kidal sudah tidak dapat ditemukan dalam bangunan candinya karena telah hilang, namun diperoleh gambar rekonstruksi Candi Kidal sehingga dapat divisualisasikan. Kitab Manasara tidak banyak mengatur tentang gala.

Tabel 5. Perbandingan Gala Kuil Brihadisvara dengan Candi Era Majapahit

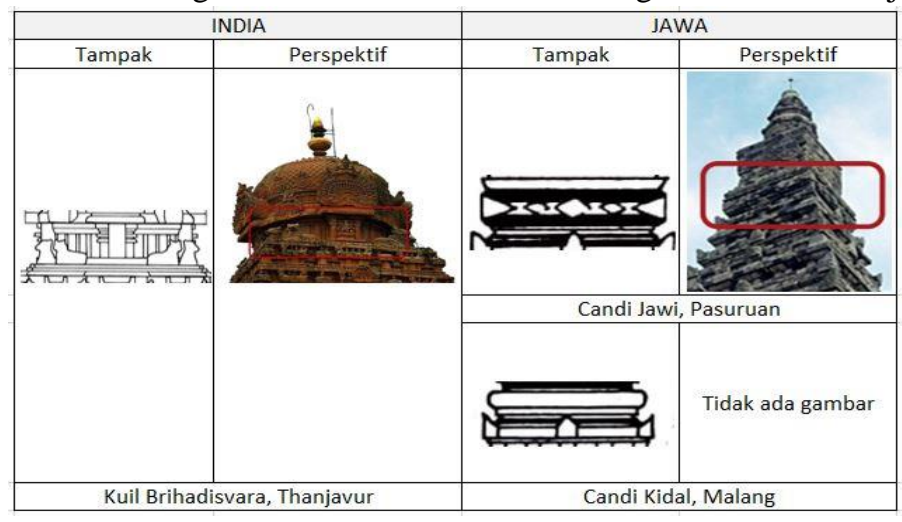

\subsubsection{PRASTARA}

Candi Kidal dan Candi Jawi memiliki bentuk atap relatif menyerupai dengan tipe Kutina pada Kuil Brihadisvara. Hal tersebut dapat dilihat dari bentuk atap Candi Kidal dan Jawi yang mengerucut. Meskipun begitu, terdapat variasi baru yang muncul pada era Majapahit. Atap berstruktur kayu muncul pada era Majapahit dan memiliki bentuk seperti Meru pada Pura yang banyak tersebar di Bali pada saat ini. Beberapa contoh candi era Majapahit yang memiliki bentuk atap menyerupai Meru adalah Candi Jago, Candi Panataran, Candi Ceto dan Candi Sukuh.

Meskipun begitu, ditemukan bahwa sejak era sebelum Majapahit, bangunan beratap kayu sudah mulai digunakan meskipun diduga bukan bangunan peribadatan ataupu candi. Hal itu dibuktikan dengan adanya relief pada Candi Prambanan yang dibangun pada abad ke-9. Selain variasi atap kayu dan ijuk, variasi candi yang lain seperti candi bentar juga muncul pada era Majapahit. Meskipun begitu, candi bentar lebih dikenal dengan gapura tanpa atap yang dapat kita temukan seperti pada Candi Ceto.

Candi-candi Majapahit umumnya memiliki jumlah tala/ tingkatan atap yang ganjil sama seperti candi-candi era Mataram Kuno dan di India. Sedangkan Manasara sendiri tidak mengharuskan jumlah tala harus ganjil. 


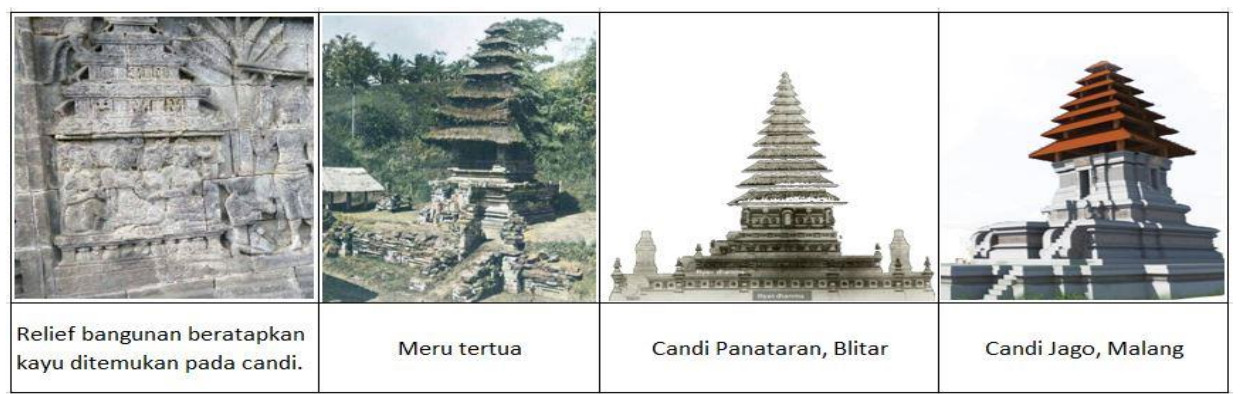

Selain itu, perlu diperhatikan pula bahwa candi-candi Majapahit sering menerapkan kosep pembagian tiga tidak hanya pada sosok secara keseluruhan, namun dalam tingkatan pada bagian kaki dan atapnya juga seperti yang dapat kita perhatikan pada gambar di bawah ini.
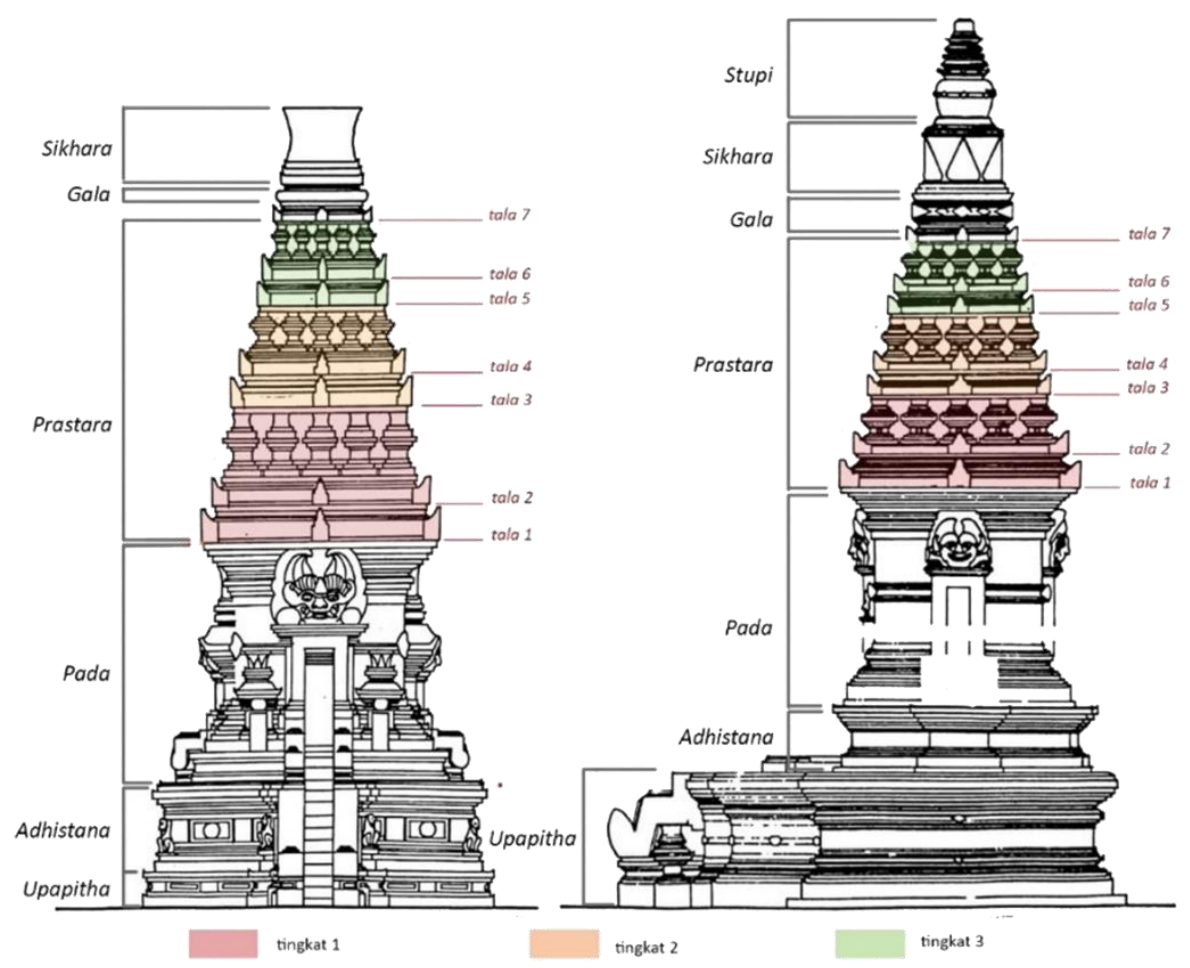

Gambar 7. Konsep Pembagian Tiga Melebur dengan Pembagian Tujuh Menurut Manasara

Terdapat beberapa ornamen penting yang berpengaruh terhadap sosok kuil/ candi. Ornament-ornamen yang berada pada bagian prastara umumnya termasuk dalam ornamen non sacral dan merupakan elemen estetis saja. Salah satunya adalah karnakuta yang terdapat pada kuil India. Karnakuta merupakan ornamen yang berada pada elemen prastara. Karnakuta biasanya berada di ujung tala dan merupakan pembeda antar satu tala dengan yang lainnya sehingga mempermudah perhitungan jumlah tala. Pada candi-candi Majapahit, karnakuta telah hilang dan berganti menjadi antefiks yang berbentuk lebih pipih dan menyatu dengan tala. Sebagai contoh, antefiks dapat dilihat pada prastara Candi Jawi dan Kidal sedangkan karnakuta dapat ditemukan pada prastara Kuil Brihadisvara.

\subsubsection{PADA}

Salah satu ornamen yang erat dengan elemen pada salah satunya adalah ornamen torana-Makara. Pada kuil India, biasanya torana-makara merupakan pahatan yang berada di atas pintu menuju garbagrha yang berwujud makhluk mitologi disebut kala. Kala pada candi Majapahit biasanya berwujud muka raksasa yang jelas atau yang biasa disebut kirthimukha. 
Sedangkan pada kuil di India, kala sulit ditemukan dan apabila ada bentuknya tidak memiliki wujud muka yang jelas.

Makara pada candi-candi Majapahit dipahat bertolak belakang dan memiliki letak di bawah pintu masuk menuju garbagrha seperti yang sudah ada pada candi-candi Mataram Kuno. Hal ini tentu berbeda dengan yang terdapat pada kitab Manasara dan Kuil India. Dijelaskan pada kitab Manasara bahwa Makara dipahat saling berhadapan dan terletak di atas kolom pada pintu masuk yang menyatu dengan lengkung pintu. Pada beberapa kuil, makara menyatu dengan kala sehingga sama-sama membingkai pintu masuk menuju garbagrha.

Tabel 7. Perbandingan Kala-Makara Kuil India dengan Candi Era Majapahit

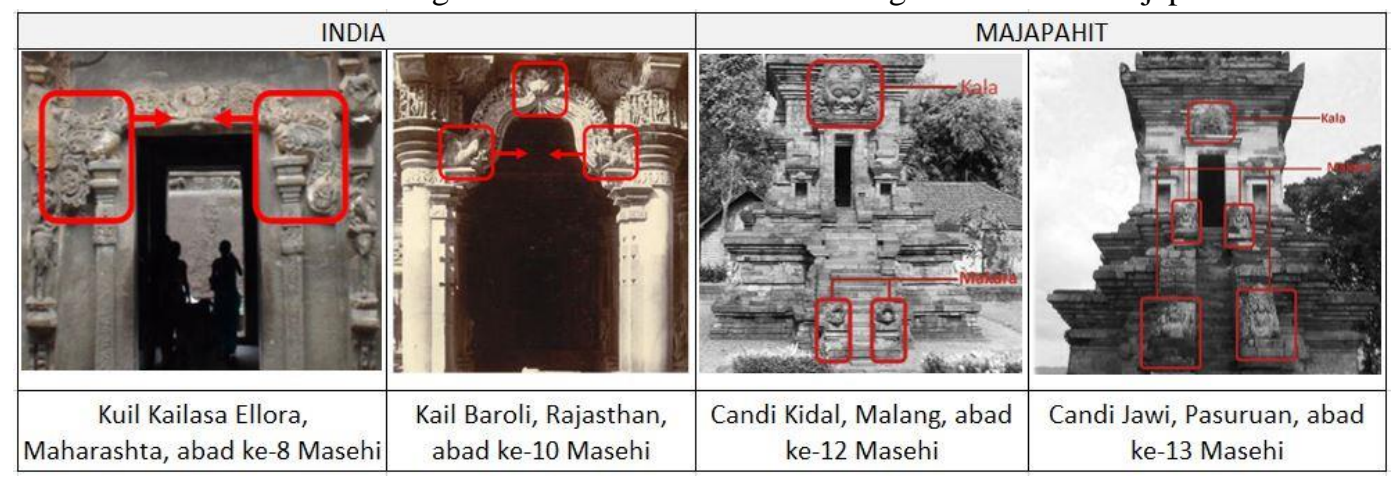

\subsubsection{ADHISTANA}

Adhistana merupakan bagian dari kaki bangunan yang berfungsi seperti umpak. Letak adhistana biasanya di atas upapitha. Namun, kadang terdapat pula bangunan yang meleburkan upapitha dengan adhistana sehingga adhistana bersentuhan langsung dengan tanah. Terdapat 20 lebih jenis Adhistana yang dibahas dalam kitab Manasara.

Tabel 8. Adhistana Candi Era Majapahit

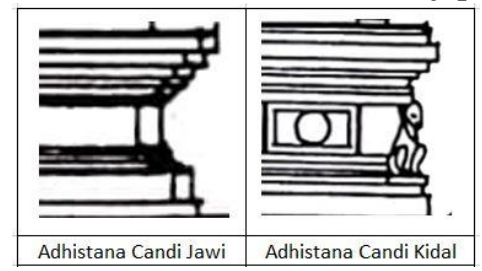

Seperti yang dapat diperhatikan pada tabel, adhistana pada candi-candi Majapahit tidak memiliki kapota dan astragal (moulding cembung torus) seperti yang biasanya terdapat dalam adhistana pada kuil-kuil Hindu di India pada umumnya. Dapat disimpulkan bahwa elemen adhistana pada candi-candi Majapahit mengalami simplifikasi.

\subsubsection{UPAPITHA}

Masyarakat Indonesia era Majapahit membuat bagian kaki candi lebih tinggi dengan alasan keagamaan. Beberapa candi seperti Candi Jago bahkan memiliki beberapa tingkat upapitha yang dilengkapi dengan tangga memanjang menuju garbagrha. Adanya tangga dengan lidah panjang pada sisi kanan dan kiri tersebut sedikit berbeda dengan beberapa kuil di India yang memiliki lidah tangga yang pendek. Pada kuil India, lidah tangga ini disebut Hastihasta.

Tabel 9. Perbandingan Hastihasta Kuil Brihadisvara dengan Candi Era Majapahit 


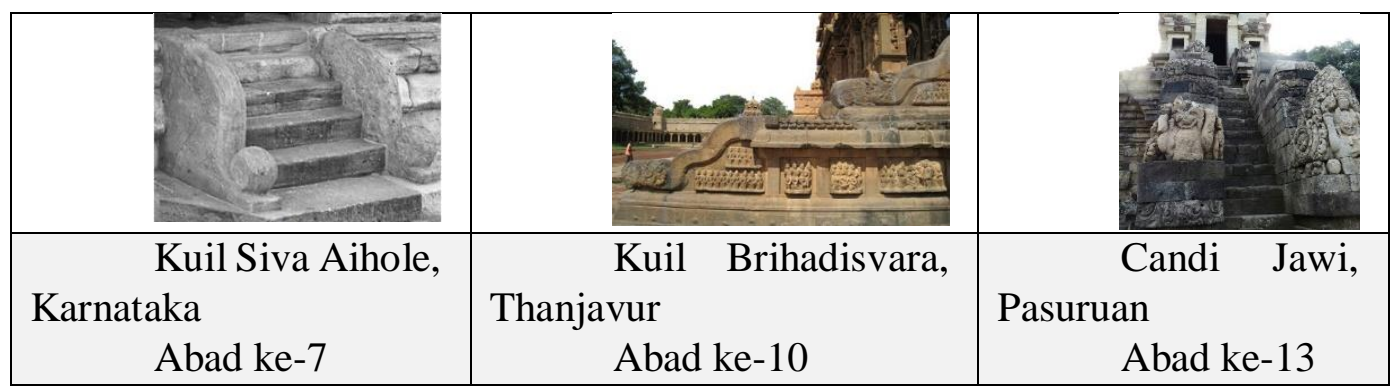

\subsubsection{KESELURUHAN}

\begin{tabular}{|c|c|c|c|c|c|c|c|c|c|c|c|c|}
\hline \multirow{3}{*}{$\begin{array}{c}\text { OBJEK STUDI } \\
\text { BAGIAN }\end{array}$} & \multirow{2}{*}{\multicolumn{2}{|c|}{$\begin{array}{l}\text { Awal } \\
\text { Kidal }\end{array}$}} & \multicolumn{6}{|c|}{ Tengah } & \multicolumn{4}{|c|}{ Akhir } \\
\hline & & & \multicolumn{2}{|c|}{ Jawi } & \multicolumn{2}{|c|}{ Jago } & \multicolumn{2}{|c|}{ Panataran } & \multicolumn{2}{|c|}{ Sukuh } & \multicolumn{2}{|c|}{ Ceto } \\
\hline & A & $M$ & A & $M$ & A & $M$ & A & $M$ & A & $M$ & A & M \\
\hline Stupi & $x$ & 0 & $\bullet$ & 3 & $x$ & 0 & $x$ & 0 & $x$ & 0 & $x$ & 0 \\
\hline Sikhara & - & 1 & - & 1 & $\mathrm{x}$ & 0 & $\mathrm{x}$ & 0 & $\mathrm{x}$ & 0 & $\mathrm{x}$ & 0 \\
\hline Gala & $\bullet$ & 1 & $\bullet$ & 2 & $x$ & 0 & $x$ & 0 & $\mathrm{x}$ & 0 & $\mathrm{x}$ & 0 \\
\hline Prastara & - & 3 & $\bullet$ & 3 & $\bullet$ & 1 & $\bullet$ & 1 & $\mathrm{x}$ & 0 & $\mathrm{x}$ & 0 \\
\hline Karnakuta & $x$ & 0 & $\mathrm{x}$ & 0 & $\mathrm{x}$ & 0 & $\mathrm{x}$ & 0 & $\mathrm{x}$ & 0 & $\mathrm{x}$ & 0 \\
\hline Sala & $\mathrm{x}$ & 0 & $\mathrm{x}$ & 0 & $\mathrm{x}$ & 0 & $\mathrm{x}$ & 0 & $\mathrm{x}$ & 0 & $\mathrm{x}$ & 0 \\
\hline Nasi & $\mathrm{x}$ & 0 & $\mathrm{x}$ & 0 & $\mathrm{x}$ & 0 & $\mathrm{x}$ & 0 & $\mathrm{x}$ & 0 & $\mathrm{x}$ & 0 \\
\hline Antefiks & $\bullet$ & 3 & $\bullet$ & 3 & $x$ & 0 & $\mathrm{x}$ & 0 & $\mathrm{x}$ & 0 & $\mathrm{x}$ & 0 \\
\hline Pada & $\bullet$ & 2 & $\bullet$ & 2 & $\bullet$ & 2 & $\bullet$ & 2 & $x$ & 0 & $\mathrm{x}$ & 0 \\
\hline Torana-Makara & - & 3 & - & 3 & $x$ & 0 & $\mathrm{x}$ & 0 & $\mathrm{x}$ & 0 & $\mathrm{x}$ & 0 \\
\hline \begin{tabular}{|l|} 
Adhistana \\
\end{tabular} & $\bullet$ & 2 & $\bullet$ & 2 & $\bullet$ & 1 & $\bullet$ & 1 & $x$ & 0 & $\mathrm{x}$ & 0 \\
\hline Upapitha & $\bullet$ & 2 & - & 2 & $\bullet$ & 1 & $\bullet$ & 1 & $\bullet$ & 1 & - & 1 \\
\hline Hastihasta & $\bullet$ & 1 & $\bullet$ & 2 & $x$ & 0 & $\bullet$ & 1 & $x$ & 0 & $x$ & 0 \\
\hline \multicolumn{2}{|c|}{ Poin kemiripan relatif } & 15 & & 20 & & 5 & & 6 & & 1 & & 1 \\
\hline & ari total & 60 & & 60 & & 60 & & 60 & & 60 & & 60 \\
\hline
\end{tabular}

Pada tabel di atas, dapat diketahui bahwa nilai kemiripan relatif candi-candi Majapahit terhadap penuturan Manasara dapat dikatakan sangat kecil. Hal tersebut berarti sosok candicandi Majapahit hanya memiliki sedikit kemiripan dengan yang dituturkan kitab Manasara dan kuil referensi. Apabila dibandingkan dengan tabel penilitian sebelumnya mengenai relasi teks vastusastra dengan candi-candi Mataram kuno, dapat diketahui bahwa nilai kemiripan candi Majapahit relatif jauh lebih kecil.

\subsection{TATA MASSA-RUANG}

Tabel 11. Perbedaan dan Persamaan aspek Tata Massa-Ruang Candi Majapahit dengan Penuturan Vastusastra-Manasara

\begin{tabular}{|c|c|c|c|c|}
\hline No & Aspek & 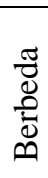 & $\underset{\tilde{E}}{\tilde{E}}$ & Keteranagan \\
\hline 1. & $\begin{array}{l}\text { Arah hadap tapak } \\
\text { candi }\end{array}$ & $\sqrt{ }$ & & $\begin{array}{l}\text { Candi Majapahit umumnya memiliki arah hadap ke } \\
\text { barat, sedangkan kuil India umumnya memiliki arah } \\
\text { hadap ke timur. }\end{array}$ \\
\hline 2. & $\begin{array}{l}\text { Elemen pada } \\
\text { tapak sesuai } \\
\text { mandala linear }\end{array}$ & $\sqrt{ }$ & & $\begin{array}{l}\text { Hanya elemen ajna dan manipura yang dapat ditemukan } \\
\text { pada candi Majapahit }\end{array}$ \\
\hline 3. & Topografi tapak & $\sqrt{ }$ & & $\begin{array}{l}\text { Candi majapahit umumnya berada pada tapak berkontur } \\
\text { atau memiliki bagian kaki yang tinggi dan bertingkat. }\end{array}$ \\
\hline 4. & $\begin{array}{l}\text { Jumlah halaman } \\
\text { dan pagar }\end{array}$ & & $\sqrt{ }$ & $\begin{array}{l}\text { Jumlah halaman candi Majapahit umumnya berjumlah } \\
\text { tiga atau ganjil sesuai dengan jumlah pagarnya sama } \\
\text { seperti pada kuil India. }\end{array}$ \\
\hline 5. & Bentuk tapak & & $\sqrt{ }$ & $\begin{array}{l}\text { Bentuk tapak candi Majapahit dan kuil Hindu di India } \\
\text { umumnya linear. }\end{array}$ \\
\hline 6. & $\begin{array}{l}\text { Ruang Dalam } \\
\text { Bangunan Utama }\end{array}$ & $\sqrt{ }$ & & $\begin{array}{l}\text { Sama-sama memiliki satu ruang dalam seperti pada kuil } \\
\text { Hindu di India pada umumnya. }\end{array}$ \\
\hline
\end{tabular}




\begin{tabular}{|l|l|l|l|l|}
\hline & & & $\begin{array}{l}\text { Meskipun begitu, candi-candi Majapahit tidak memiliki } \\
\text { mandapa dan pradakshina. }\end{array}$ \\
\hline
\end{tabular}

Yang pertama adalah perihal arah hadap candi Majapahit yang umumnya menghadap ke barat. Hal ini bertentangan dengan kuil India pada umumya yang memiliki arah hadap ke timur. Diduga hal ini disebabkan ketidaktahuan masyarakat Majapahit saat membangun candi pada masa itu sehingga lebih banyak mencontoh percandian yang sudah ada. Apabila dibandingkan dengan era Mataram Kuno, candi Majapahit umumnya menghadap ke barat terlepas dari fungsinya sedangkan hanya sebagian candi Mataram Kuno yang mengahadap ke barat. Seperti yang telah disebutkan sebelunya pula, fungsi candi tidak mempengaruhi arah hadap candi (dalam hal ini yang dimaksud adalah arah hadap tapaknya).

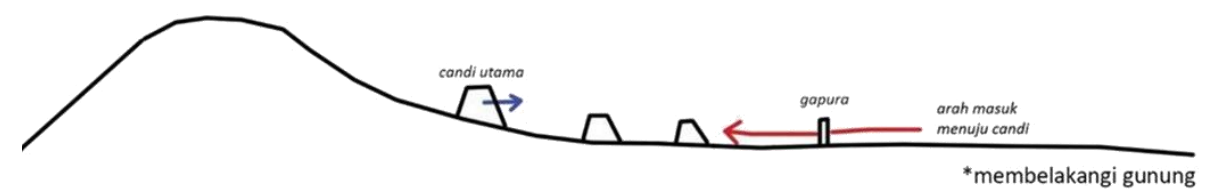

Gambar 8. Arah Hadap Candi Majapahit

Perbedaan kedua yang kentara adalah tedapat beberapa elemen yang hilang dari mandala linear dalam tata massa kompleks candi Majapahit. Umumnya, hanya chakra ajna dan manipura yang dapat ditemukan pada komplek candi Majapahit seperti Candi Panataran, Candi Ceto, dan Candi Sukuh. Sedangkan, gopuram pada kuil India juga ditemukan pada candi Majapahit, hanya saja memiliki penempatan yang berbeda dengan kuil Hindu di India. Pada kuil India, gopuram yang dimaksud merupakan pintu masuk paling akhir yang berisi halaman yang menampung candi utama dan bangunan sekunder lainnya, sedangkan pada candi-candi Majapahit bangunan-bangunan religius yang mendukung kegiatan peribadatan terletak menyebar dalam beberapa halaman sehingga gopuram/ gapuranya merupakan pintu masuk yang area terluarnya sudah bukan merupakan komplek percandian atau halaman yang sudah tidak memiliki bangunan religius.

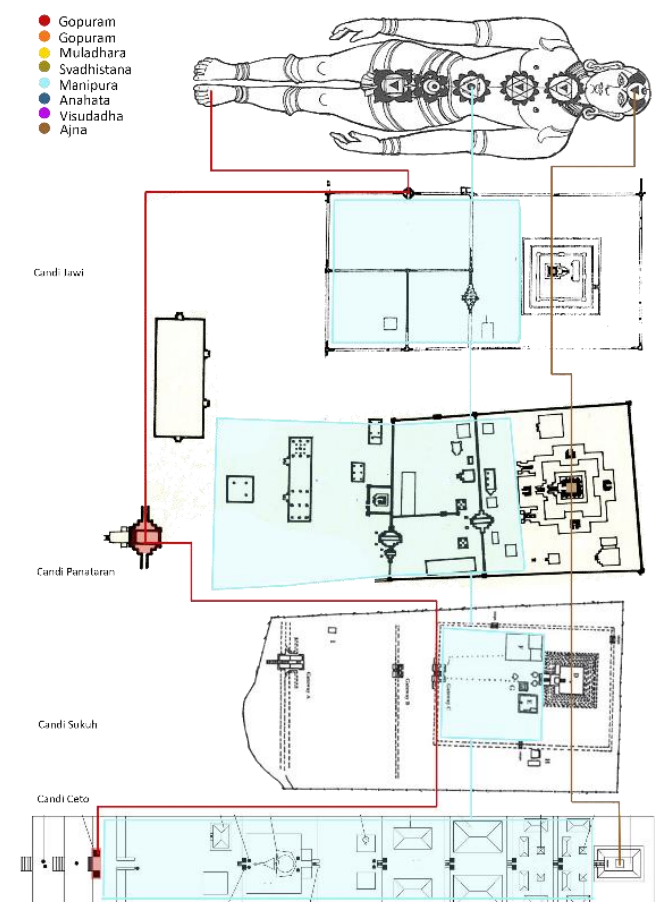

Gambar 9. Penempatan Massa dalam Gugusan Candi Majapahit berdasarkan Mandala Linear 
Perbedaan ketiga dapat diperoleh dari topografi candi Majapahit yang umumnya berkontur karena berada di bukit, beberapa contohnya adalah candi Ceto dan Sukuh. Dalam beberapa kasus seperti Candi Jago yang dibangun pada permukaan yang datar, bangunan candinya dibuat semakin tinggi dengan bagian kaki yang bertingkat-tingkat seperti punden berundak. Hal ini tentunya berbeda dengan yang ditemukan pada kuil-kuil India pada umumnya yang berada di permukaan yang datar.

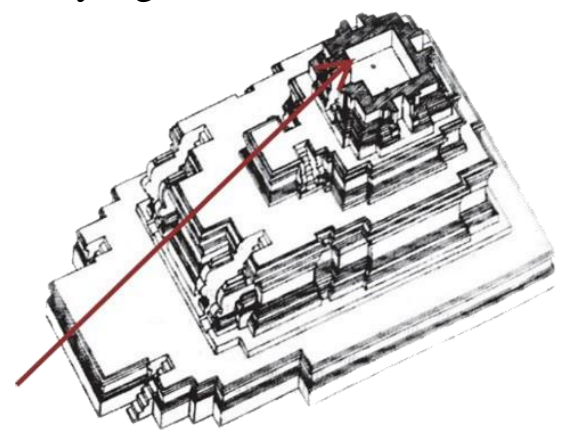

Gambar 10. Kaki Candi Jago yang Diibuat Bertingkat

Meskipun banyak memiliki perbedaan, keduanya memiliki beberapa kesamaan pula. Salah satunya adalah jumlah halaman yang sesuai dengan jumlah pagar/ pintu pembatasnya. Biasanya candi Majapahit memiliki tiga pagar yang membagi tiga halaman seperti yang ditemukan pada kuil Brihadisvara. Namun, terdapat pengecualian pada Candi Ceto (tujuh halaman) dan Candi Jawi (dua halaman). Selain itu, candi-candi Majapahit juga memiliki tapak berbentuk persegi panjang seperti ditemukan pada kuil India pada umumnya. Hal ini merupakan anomali dari perkembangan bentuk tapak candi karena pada era sebelumnya tapak candi umumnya berbentuk persegi.

Tabel 12. Perbandingan Jumlah Halaman dan Pagar Candi-Candi Majapahit dengan Penuturan Vastusastra-Manasara

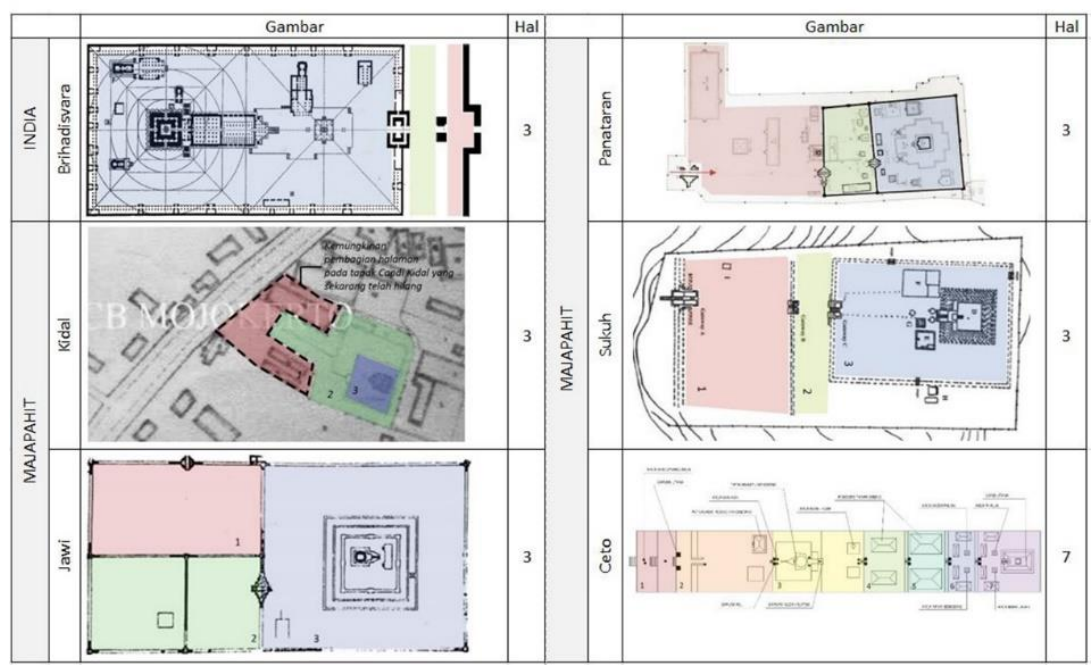




\section{KESIMPULAN}

\subsection{SOSOK BANGUNAN}

Sosok bangunan pada candi-candi Majapahit memiliki relasi yang kurang erat dengan skema elemen vimana yang dituturkan dalam Manasara dan kuil-kuil India. Ketidaksesuaian berikut dapat ditemukan dalam beberapa aspek. Yang pertama adalah beberapa elemen dari skema yang berasal Manasara tidak ditemukan pada candi Majapahit. Dari keenam candi yang dipilih sebagai objek penelitian, hanya Candi Jawi yang memenuhi pembagian elemen vimana secara keseluruhan dan memiliki stupi berbentuk stupa, sedangkan Candi Kidal tidak memiliki stupi.

Terdapat kedua kemungkinan yang dapat menjadi alasan hilangnya stupi pada Candi Kidal. Yang pertama, diduga pada awalnya, elemen stupi pada Candi Kidal ada namun kini sudah hilang atau rusak. Dugaan yang kedua adalah elemen stupi digambarkan dengan kekosongan yang menunjukkan elemen tertinggi sebagai sesuatu yang abstrak seperti padmasana yang ada di Bali. Selain itu, bentuk sikhara yang menyerupai pripih memperkuat konsep tersebut karena pripih merupakan simbol raja yang telah wafat sehingga rohnya dianggap telah menyatu dengan dewa sehingga tidak berwujud lagi (moksa). Sedangkan, Candi Induk Panataran, Candi Jago, Candi Sukuh dan Candi Ceto telah mengalami perubahan bentuk atap menyerupai meru di Bali. Diduga perubahan bentuk atap ini merupakan hasil dari masuknya Buddhisme dari China yang erat dengan pagoda yang menggunakan elemen dugong. Selain itu, muncul inovasi baru dalam bentuk atap bertingkat (meru) yang menggunakan struktur kayu. Struktur ini dipandang mampu bertahan dari gempa dibandingkan dengan material batu.

Perbedaan yang kentara juga dapat dilihat dari bagian kaki candi-candi Majapahit yang umumnya memiliki proporsi yang lebih tinggi dibandingkan dengan proporsi kuil India. Beberapa dari kaki candi Majapahit bahkan terdiri dari beberapa tingkat seperti pada candi Candi Jago dan Candi Induk Panataran. Hal ini diduga karena muncul kembali dominasi yang kuat kepercayaan lokal yang menyembah arwah nenek moyang sejak zaman megalitikum sehingga menghasilkan bentuk punden berundak yang dahulu digunakan sebagai tempat penyembahan untuk arwah nenek moyang. Bentuk punden berundak tersebut semakin jelas diwujudkan pada kaki candi-candi Majapahit yang dibangun pada era Majapahit akhir seperti pada kaki Candi Ceto dan Sukuh.

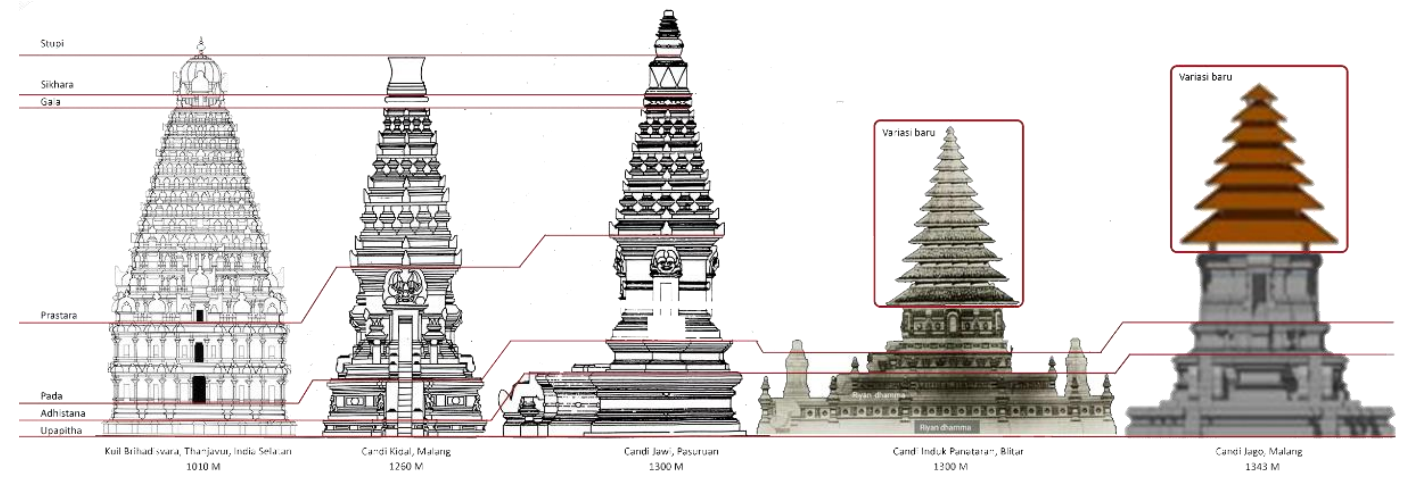

Gambar 11. Perubahan Sosok Candi Era Majapahit berdasarkan Waktu

Selain itu, terdapat beberapa ornamen yang umumnya ada pada kuil India namun tidak ditemukan pada candi Majapahit. Beberapa ornamen tersebut seperti karnakuta dan sala namun digantikan dengan antefiks sebagai ganti karnakuta dan sala. Elemen makara jarang ditemukan pada era candi Majapahit dan biasanya elemen ini digantikan dengan bentuk naga pada tangga candi. Sementara makara lebih banyak digunakan untuk pancuran air. Sebaliknya ditemukan juga ornamen yang muncul pada candi Majapahit namun tidak merupakan elemen yang umum ditemukan pada kuil India, salah satunya adalah adanya Kala. 
Secara singkat, dapat dikatakan bahwa pembagian tujuh menurut Manasara pada sosok candi Majapahit masih ada meskipun melebur dengan pembagian tiga dari kosmologi Hindu yang dipercayai masyarakat era tersebut. Namun, apabila dibandingkan dengan hasil analisis candi Mataram Kuno pada penelitian sebelumnya, diketahui bahwa candi-candi Majapahit memiliki nilai kemiripan lebih kecil dari pada candi Mataram Kuno. Hal tersebut diduga karena adanya pencampuran budaya lain dan meningkatnya kreatifitas dan lokalitas pada saat itu. Contohnya, pada era Mataram Kuno, umumnya elemen dari skema pembagian tujuh masih dapat dijumpai secara lengkap, meskipun terdapat sedikit pebedaan telah ditemukan sedangkan pada era Majapahit, pembagian tujuh pada candi tersebut lebih banyak ditemukan secara tidak lengkap.

\subsection{TATA MASSA-RUANG}

Tata ruang dan massa candi Majapahit memiliki relasi yang kurang dengan penuturan Manasara dan kuil-kuil India. Perbedaan ini meliputi arah hadap bangunan utama candi, elemen tapak yang tidak sesuai dengan mandala linear, dan topografi tapak candi Majapahit. Bangunan utama candi-candi Majapahit umumnya memiliki arah hadap membelakangi gunung. Hal ini tentu berbeda dengan arah hadap bangunan utama kuil India yang umumnya menghadap timur. Namun terdapat pengecualian pada Candi Jawi yang bangunan utamanya menghadap gunung yang bearad di timur (meskipun gapura utamanya tetap membelakangi gunung/ mengarah ke barat). Hal ini diduga karena konsep penyembahannya yang dibuat menghadap barat atau membelakangi gunung. Selain itu, pintu masuk (gopuram) kuil India umumnya berada di tengah tapak sedangkan pintu masuk candi Majapahit umumya menyerong. Pada tapak candi-candi Majapahit juga ditemukan bahwa tapaknya dibuat berundak menyerupai punden karena dipengaruhi kebudayaan megalitikum. Hal tersebut tentu tidak ditemukan pada penuturan Manasara mengingat dataran di India umumya landai atau datar sama sekali. Pada candi-candi Majapahit juga tidak diperoleh elemen chakra yang lengkap seperti yang seharusnya ada pada kuil-kuil yang berdasarkan vastusastra-Manasara. Hanya elemen ajna (garbagrha) dan manipura (pelataran) yang ditemukan pada tata massa candi-candi Majapahit.

Sedangkan, terdapat beberapa kesamaan yang ditemukan pada tata massa candi-candi Majapahit dengan kuil Hindu di India Selatan seperti bentuk tapak candi yang linear dan jumlah halaman yang umumnya dibagi tiga. Meskipun begitu, mengenai bentuk tapak, sesungguhnya Manasara tidak mengharuskan bentuk linear melainkan memberi peluang bagi berbagai bentuk lewat macam-macam bentuk mandala yang disediakan. Hal serupa juga terjadi pada jumlah halaman yang dibagi tiga yang tidak ditemukan bahasannya dalam Manasara. Diduga bahwa tata massa candi-candi Majapahit lebih didominasi oleh pengaruh kebudayaan lokal seperti kebudayaan megalitikum sehingga muncul bentuk tapak berundak. Selain itu, konsep pembagian tiga juga mendominasi dasar pembangunan candi tidak hanya pada sosok melainkan juga pembagian halaman pada tapak sehingga tercipta halaman depan, tengah, dan belakang.

Tata ruang dalam candi Majapahit juga berbeda dengan kuil Hindu di India yang umumnya memiliki garbagrha, pradakshina path dan mandapa-mandapa. Pada candi Majapahit, elemen yang dapat ditemukan hanya garbagrha sedangkan pradakshina-path diduga diwujudkan pada halaman candi.

Hasil penelitian ini menunjukkan adanya perbedaan antara candi-candi Majapahit dengan penuturan Manasara. Hal ini diduga karena vastusastra tidak dikenal baik pada era Majapahit. Sehingga kemungkinan pembangunan candi pada masa tersebut mengacu pada candi-candi era sebelumnya yaitu era Mataram Kuno yang kemudian dilebur dengan kebudayaan baru (China) dan budaya lokal seperti kebudayaan megalitikum. 


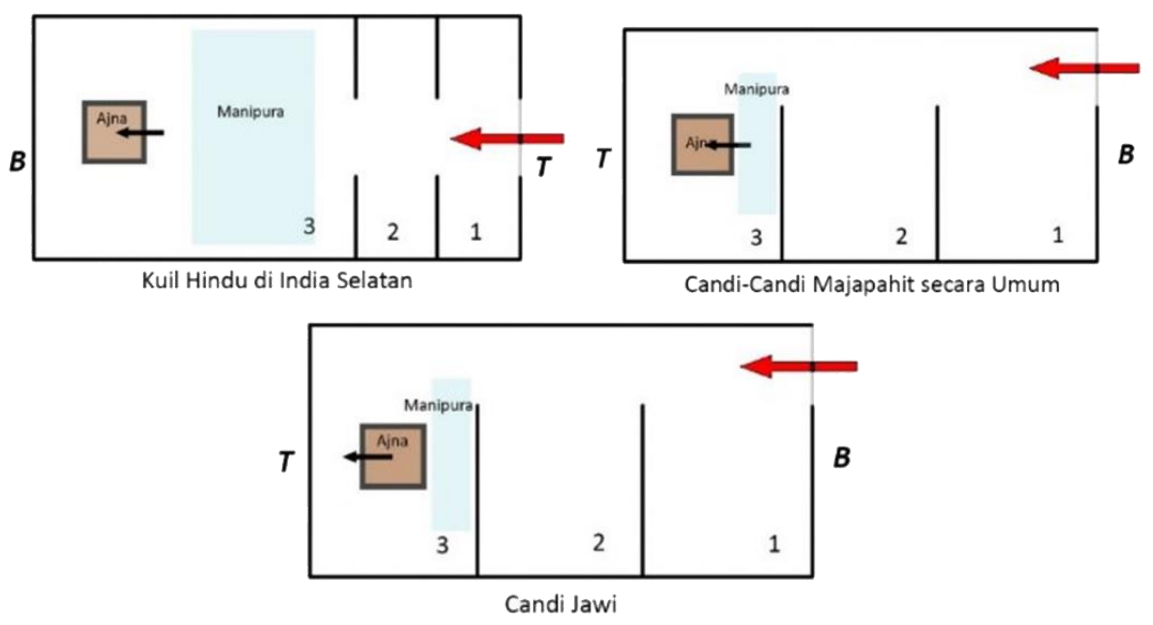

Gambar 12. Perbedaan Tata Massa Candi Era Majapahit dengan Penuturan Manasara

Secara umum, penelitian ini menunjukkan bahwa penggunaan vastusastraManasara semakin berkurang dari era Mataram Kuno sampai Majapahit. Hal ini dilihat dari nilai kemiripan pada sosok candi pada kedua era tersebut semakin berkurang. Banyak elemen yang disebutkan dalam kitab Manasara sudah tidak dapat ditemukan atau berubah bentuknya terutama pada candi-candi Majapahit akhir. Dominasi kebudayaan lokal juga diduga meningkat akibat kondisi sosial-politik masa itu sehingga memunculkan gaya baru dalam arsitektur seperti yang telah disebutkan di atas.

\section{DAFTAR PUSTAKA}

\section{Buku}

(2006) Majapahit Trowulan, Indonesian Heritage Society. ISBN 979-95634-6-1 (1934) Manasara Series Vol. IV: Indian Architecture according to Mānasāra Śilpaśāstra, Oxford University Press.

(1934) Manasara Series Vol. V: Indian Architecture according to Mānasāra Śilpaśāstra, Oxford University Press.

Acharya, Prasanna Kumar (1934) Manasara Series Vol. II: Indian Architecture according to Mānasāra Śilpaśāstra, Oxford University Press.

Atmadi, Pramono (1994) Some Architectural Design Principles of Temples in Java, Gajah mada University Press. ISBN 979-420-085-9

Hardy, Adam (1995) Indian Temple Architecture: Form and Transformation, Abhinav Publications. ISBN 978-817-017-312-0

Kartodirdjo, Prof. DR. Sartono, dkk.(1992).700 Tahun Majapahit (1293-1993): Suatu Bunga Rampai. Surabaya: Universitas Gajah Mada.

Kinney, Ann R. (2003) Worshiping Siva and Buddha : the temple art of East Java, University of Hawai'I Press.

Munadar, Agus Aris (2015) Keistimewaan Candi-Candi Zaman Majapahit, Penerbit Wedatama Widya Sastra. ISBN 978-602-273

Sachdev, Vibhuti (2002) Building Jaipur: the making of an Indian city, Reaktion Books LTD, ISBN 1-86189-1377

\section{Jurnal, Skripsi, Tesis} (2003) Kajian Estetika Desain Arsitektur Majapahit, Lembaga Penelitian Universitas Katolik Parahyangan 
(2017) " The Characteristic Features of Megalithic Culture in The Architecture of Temples on The Island of Java (From The Ancinet to the Middle and Late Classical Eras)", Jurnal RISA vol. 1 no. 3 edisi Juli. ISSN 2548-8074

(2016) "The Genealogy of the Architectural Shape of Minaret-Shaped

Temples (Candi) in Indonesia", International Journal of Academic Research vol. 8 no. 5 September issue, IJAR. ISSN 2348-7666

Alessandro, Jason (2019) Komparasi Candi Prambanan dengan Kuil Brihadisvara, Thanjavur Ditinjau dari Tata Ruang, Tata Massa, Sosok Bangunan dan Tektonika, Universitas Katolik Parahyangan

Citra, Irwan (2015) Perkembangan Tatanan Massa dan Ruang rasitektur Candi di Jawa (Dari Masa Klasik Tua, Klasik Tengah, dan Klasik Muda), Universitas Katolik Parahyangan

Dibya, Cista (2019) Komparasi Kuil Meenakshi Amman di India Selatan dengan Pura Besakih di Indonesia Ditinjau dari Tata Massa, Ruang, Sosok dan Ornamen, Universitas Katolik Parahyangan

Herwindo, Rahadhian P (1999) Kajian Tipo-Morfologi Arsitektur Candi di Jawa, ITB

Patnayaka, Ravindra (2019) Morphology and Character of Indian Temple Form, GITAM, ISSN 2277-2723

Perdana, Aditya B (2019) Kajian Relasi Arsitektural Candi Era Majapahit dengan Vāstuśāstra -Mānasāra, Universitas Katolik Parahyangan

Tribinuka, Tjahja (2014) Rekonstruksi Arsitektur Kerajaan Majapahit dari Relief, Artefak dan Situs Bersejarah, Institut Teknologi Sepuluh November

\section{Internet}

CNN Indonesia (2018, September 30) Inside Indonesia: Trowulan, Warisan Kerajaan Majapahit [berkas video]. Diakses dari https://www.youtube.com/watch? $\mathrm{v}=\mathrm{QPmAslEDyhI} \&$ list $=\mathrm{WL} \&$ index $=5 \& \mathrm{t}=0 \mathrm{~s}$

Zakaria Production (2017, Desember 10)Misteri Candi Cetho yang Akan Membuat Anda Tercengang [berkas video]. Diakses dari https://www.youtube.com/watch?v=svxNmb8YCfo\&list=WL\&index $=18 \& \mathrm{t}=0 \mathrm{~s}$ 